Acta Technologica Agriculturae 3

Nitra, Slovaca Universitas Agriculturae Nitriae, 2014, pp. 75-79

\title{
GAS EMISSIONS IN COMBUSTION OF BIOFUEL
}

\author{
Ivan VITÁZEK*, Janko KLÚČIK, Tomáš PINTER, Zuzana MIKULOVÁ \\ Slovak University of Agriculture in Nitra, Slovak Republic
}

\begin{abstract}
Nowadays, biomass or more precisely biofuel is more and more being exploited as a substitute for fossil fuels for heating as well as for example for heating a drying environment. This contribution focuses on assessing a heat source by combusting various types of solid biofuels. It is a boiler VIGAS 25 with AK 2000 regulation for heating a family house. Gaseous emissions were measured using a device TESTO 330-2LL. Firewood, peat briquettes, bark briquettes and hardwood briquettes were burnt. Results of experimental measurements concerning the production of gaseous emissions are processed in tables and graphs depending on boiler performance and combustion time.
\end{abstract}

Keywords: heat source, solid biofuel, emissions, briquette, firewood

The current way of life in the world is dependent on nonrenewable energy sources, especially fossil fuels that arose millions of years ago; therefore, it is impossible to restore them from the perspective of a single human life. Forasmuch as their consumption is constantly increasing and stocks are falling, but also taking into account environmental aspects, there is a need to find new energy sources that could replace fossil fuels used until now.

As regards the versatility of use, the energy of biomass generated by accumulation of solar energy in all organisms by means of chemical processes is of prime importance. Its energy can be converted by direct combustion into heat energy for heating houses and flats, or it can be further converted into electrical energy. In case of industry, it is possible to use all types of biomass. In Slovakia, it is mainly a solid form for heating in urban heating plants. Similarly it looks with agricultural crop dryers where wastes from agriculture represent an easily available and cheap source of energy (Vitázek et al., 2010).

However, the combustion of biomass has its drawbacks. In recent years, the biomass-based clean fuel mainly in the form of pellets and briquettes has become very popular. However, when recalculating a calorific value, their price begins to approach the price of natural gas nowadays. Besides energy and economic aspects, also environmental aspects are increasingly being promoted in characterizing and evaluating biofuels. The results of analyses and measurements of flue gases produced by combustion of biofuels indicate that flue gases also contain other aliphatic and aromatic hydrocarbons, $\mathrm{CO}$ and nitrogen oxides in addition to the main products of oxidation of carbon and hydrogen - $\mathrm{CO}_{2}$ and $\mathrm{H}_{2} \mathrm{O}$ (Vitázek et al., 2012). For that reason, it should be ceased from the opinion about the ecological harmlessness of producing heat from wood and wood waste, whereby attention should be paid to the development and enhancement of technological processes of combusting biofuel in furnaces of heat generators (Dzurenda, 2004).

This contribution contains the results of measuring the concentration of gaseous emissions on a heat source for heating a family house by burning wood biomass.

\section{Material and methods}

The subject of our study was the hot-water gas boiler VIGAS 25 with AK 2000 regulation, which is used for burning firewood or wood briquettes, or alternatively woodchips, etc. and for heating family houses (Pinter, 2013).

Boiler parameters: manufacturer VIMAR, nominal output $25 \mathrm{~kW}$, output range $5-31 \mathrm{~kW}$, burning efficiency $85.49 \%$, max. operating pressure $0.3 \mathrm{MPa}$, chimney/vertical blast $15-20 \mathrm{~Pa}$, feeding tank capacity $120 \mathrm{dm}^{3}$, maximum electrical input power $70 \mathrm{~W}$, noise level $45.5 \mathrm{~dB}$.

This boiler is used for burning firewood with a recommended humidity up to $20 \%$. As an alternative fuel, the manufacturer recommends wood briquettes, but also woodchips, sawdust and wood shavings; however, those must be burnt together with wood pieces.

The fuel is dried and gasified in a feeding tank, where wood gas is generated and flows through a pyro-concrete jet to a combustion chamber (it burns there with the help of secondary air). Flue gases are rapidly cooled down in an exchanger. Unburnt residues are swept out of the combustion chamber. For firing, the boiler has a fire flap controlled by a draw rod in its front part. In order for the boiler to be easy to use, it has a control unit AK 2000 placed in the upper part of the boiler. The used control unit provides a very efficient burning of various types of biofuel. In case of a long-term blackout or automatic control failure, it is possible to fire with opening the chimney flap and leaving the lower door open. With this type of firing, it is necessary to check output water temperature more frequently and fill up with a smaller amount of fuel because the boiler could be overheated by filling the tank to the full (Pinter, 2013).

We have chosen four types of biofuels for measurements, i.e. firewood, peat briquettes, bark briquettes and hardwood briquettes. These types were chosen intentionally, in order to be able to compare emissions when burning the fuel which the boiler is determined for, with an alternative fuel or a fuel not recommended by the manufacturer. 
Emissions were measured by TESTO $330-2$ LL. It is a flue gas analyser for measuring several parameters and saving them in memory. We have recorded the following parameters: $\mathrm{O}_{2} \%, \mathrm{CO} p \mathrm{pm}, \mathrm{CO}_{2} \%, T_{s}^{\circ} \mathrm{C}$ (flue gas temperature), $q A \%$ (chimney/vertical loss) $\eta \%$ (efficiency), $\lambda$ (air surplus), $\mathrm{NO}$ ppm, $\mathrm{NO}_{x}$ ppm, chimney/vertical blast Pa.

To begin with recording of emissions production, it is necessary to choose the option Flue gas measurement and confirm the choice. If no fuel is selected, it is necessary to select the type of fuel before the beginning of measurement.

The gas sensor of the device was placed approximately $900 \mathrm{~mm}$ from the output of the flue pipe from the boiler and, at the same time, the end of the sensor was placed approximately to the middle of the chimney to obtain the best possible results.

The humidity of all the fuel types was determined by a laboratory furnace Memmert UFE 400 and calculated as an average from three samples. The weight of samples was measured by scales KERN EG 420 with a precision of $0.001 \mathrm{~g}$. Samples were dried at a temperature of $105^{\circ} \mathrm{C}$ up to a constant weight.

The following relationship was used to calculate humidity from the determined weight of samples:

$$
w=\frac{m_{1}-m_{2}}{m_{1}}
$$

where:

$m_{1}$ - original weight

$m_{2}$ - dry mass weight
The content of carbon monoxide in flue gas was calculated as follows:

$$
\mathrm{CO}\left(\mathrm{mg} \cdot \mathrm{m}^{-3}\right)=\frac{21 \%-\mathrm{O}_{2 \text { ref }}}{21 \%-\mathrm{O}_{2}} \times 1.25 \mathrm{CO}(\mathrm{ppm})
$$

where:

$21 \%$ - concentration of oxygen in the air

$\mathrm{O}_{2}$ - measured concentration of oxygen in percentages

$\mathrm{O}_{2 \text { ref }}$ - reference proportion of oxygen (depends on fuel) in percentages

The content of nitrogen oxides in flue gas was calculated as follows:

$$
\mathrm{NO}_{\mathrm{x}}\left(\mathrm{mg} \cdot \mathrm{m}^{-3}\right)=\frac{21 \%-\mathrm{O}_{2 \text { ref }}}{21 \%-\mathrm{O}_{2}} \times 1.25 \mathrm{NO}_{\mathrm{x}}(\mathrm{ppm})
$$

where:

$21 \%$ - concentration of oxygen in the air

$\mathrm{O}_{2}$ - measured concentration of oxygen in percentages

$\mathrm{O}_{2 \text { ref }}$ - reference proportion of oxygen (depends on fuel) in percentages

\section{Results and discussion}

The first test of emissions for firewood (including other parameters) was performed after about 30 minutes from stoking, and other tests were carried out approximately in 30 minute intervals to point out to differences at different

\begin{tabular}{|c|c|c|c|c|c|c|c|c|c|}
\hline \multirow[t]{2}{*}{ No } & \multirow[t]{2}{*}{$\mathrm{O}_{2}$ in $\%$} & \multirow[t]{2}{*}{$\mathrm{CO}_{2}$ in \% } & \multicolumn{2}{|c|}{$\mathrm{CO}$} & \multirow[t]{2}{*}{$T_{s}$ in ${ }^{\circ} \mathrm{C}$} & \multirow[t]{2}{*}{$T_{v}$ in ${ }^{\circ} \mathrm{C}$} & \multirow[t]{2}{*}{ qA in $\%$} & \multirow[t]{2}{*}{$\eta$ in \% } & \multirow[t]{2}{*}{$\lambda$} \\
\hline & & & ppm & $\mathrm{mg} \cdot \mathrm{m}^{-3}$ & & & & & \\
\hline 1 & 12.0 & 8.70 & 1,739 & $2,415.3$ & 100 & 25.3 & 6.4 & 93.6 & 2.33 \\
\hline 2 & 17.6 & 3.29 & 1,393 & $5,121.3$ & 55.8 & 26.4 & 7.1 & 92.9 & 6.18 \\
\hline 3 & 19.4 & 1.55 & 1,620 & $12,656.2$ & 39.9 & 27.6 & 5.4 & 94.6 & 13.1 \\
\hline 4 & 20.1 & 1.42 & 1,440 & $20,000.0$ & 27.8 & 26.5 & 4.8 & 93.1 & 16.3 \\
\hline 5 & 19.1 & 1.84 & 1,757 & $11,559.2$ & 46.8 & 27.0 & 7.3 & 92.7 & 11.1 \\
\hline 6 & 19.6 & 1.35 & 1,793 & $16,008.9$ & 37.7 & 26.3 & 5.7 & 94.3 & 15.0 \\
\hline 7 & 18.2 & 2.71 & 2,984 & $13,321.4$ & 57.7 & 25.9 & 8.1 & 91.9 & 7.5 \\
\hline 8 & 19.2 & 1.74 & 1,404 & $9,750.0$ & 46.1 & 26.3 & 7.7 & 92.3 & 11.7 \\
\hline
\end{tabular}
boiler performances. The results are shown in Figure 1,

\begin{tabular}{|c|c|c|c|c|c|}
\hline \multirow[t]{2}{*}{ No } & \multicolumn{2}{|c|}{ NO } & \multicolumn{2}{|c|}{$\mathrm{NO}_{\mathrm{x}}$} & \multirow{2}{*}{$\begin{array}{c}\text { Boiler } \\
\text { performance in \% }\end{array}$} \\
\hline & ppm & $\mathrm{mg} \cdot \mathrm{m}^{-3}$ & ppm & $\mathrm{mg} \cdot \mathrm{m}^{-3}$ & \\
\hline 1 & 21 & 47.8 & 24 & 54.7 & 100 \\
\hline 2 & 14 & 84.4 & 17 & 102.5 & 40 \\
\hline 3 & 11 & 140.9 & 13 & 166.5 & 10 \\
\hline 4 & 10 & 227.8 & 10 & 227.8 & 0 \\
\hline 5 & 16 & 172.6 & 17 & 183.4 & 40 \\
\hline 6 & 23 & 336.8 & 26 & 380.71 & 100 \\
\hline 7 & 19 & 139.1 & 23 & 168.4 & 80 \\
\hline 8 & 15 & 170.8 & 17 & 193.6 & 60 \\
\hline
\end{tabular}

Table 1 Results of emissions for burning firewood 


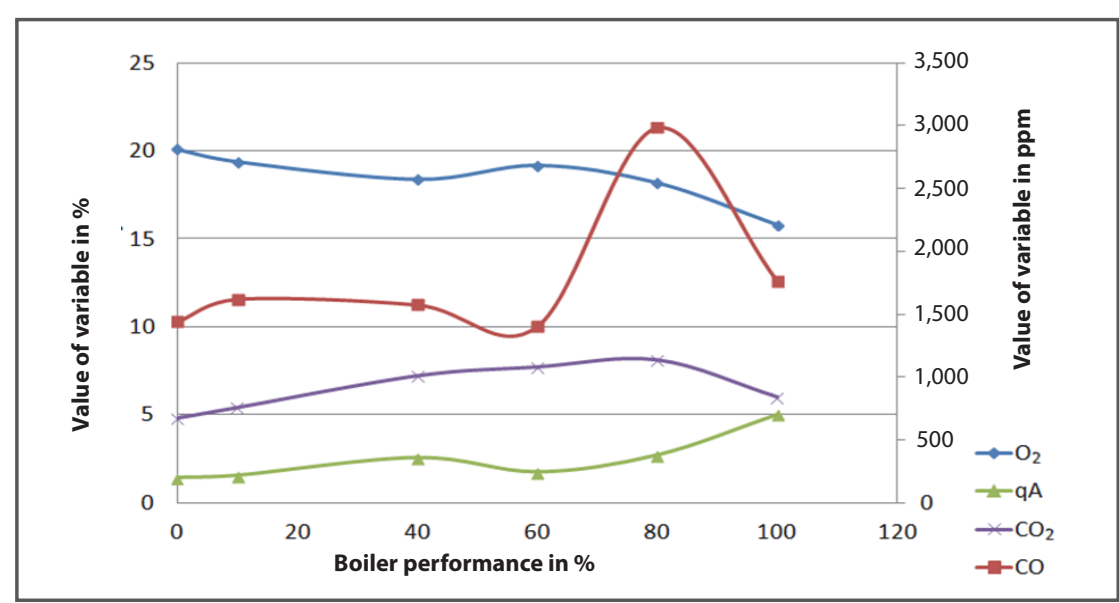

Figure 1 Effect of boiler performance on levels of oxygen, carbon dioxide and carbon monoxide in flue gas, and chimney/vertical loss at given performance

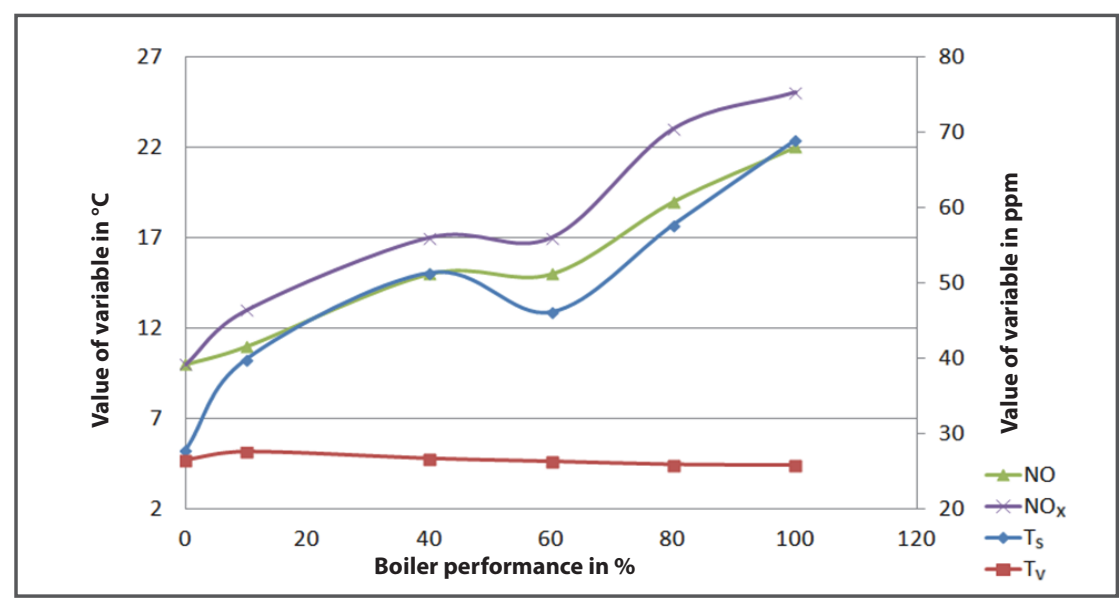

Figure 2 Effect of boiler performance on levels of nitrogen oxides and nitric oxide in flue gas and flue gas temperature, and the course of ambient temperature

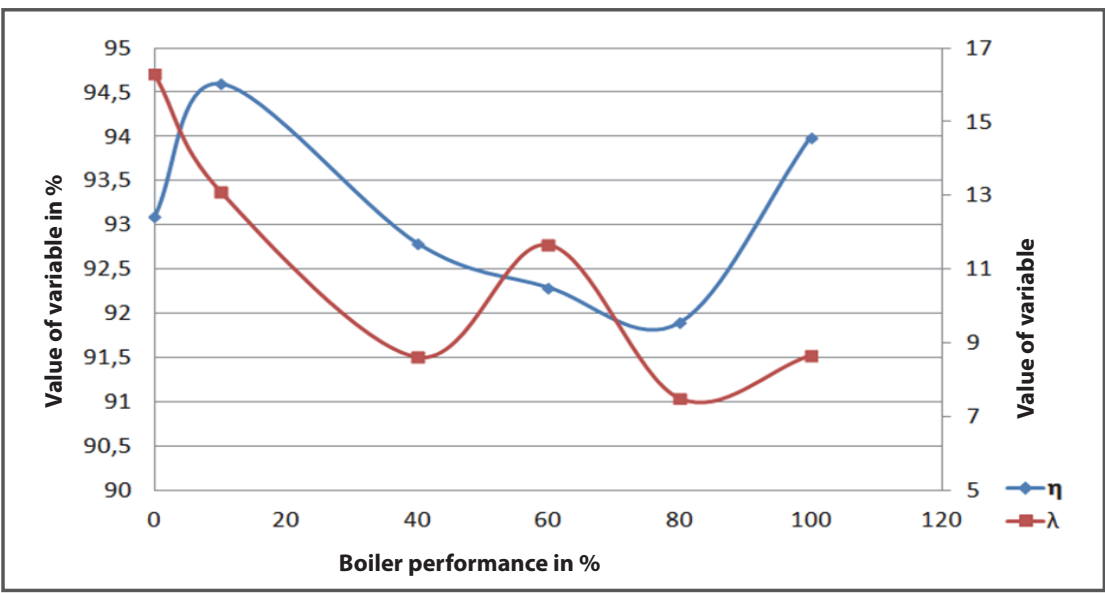

Figure 3 Effect of boiler performance on efficiency and air surplus

whereby boiler performance is specified with each test. At a $100 \%$ performance, we have also performed the chimney/vertical blast test, reaching the value $11 \mathrm{~Pa}$ at the maximum flue gas temperature of $81.1^{\circ} \mathrm{C}$

Figure 1 illustrates the effect of boiler performance on emissions of oxygen, carbon dioxide and carbon monoxide in flue gas, and chimney loss at the given performance during the burning of firewood. With respect to two tests at a $100 \%$ and $40 \%$ performance, we marked the average value of these tests to the graph. At an $80 \%$ performance of the boiler, we can see a significant increase of carbon monoxide emissions in flue gas, which can be caused by the fire-through and movement of the fuel in the storage tank.

Figure 2 shows the effect of boiler performance on emissions of nitrogen oxides and nitric oxide in flue gas and flue gas temperature, and the course of ambient temperature during this test. It is obvious from the graph that the production of nitrogen oxide with this type of fuel is dependent on the temperature of flue gas.

Figure 3 illustrates the effect of boiler performance on effectiveness and air surplus. It is possible to observe the lowest boiler effectiveness at $80 \%$, which could have been caused, similarly to higher emissions of carbon monoxide, by fuel movement in the storage tank.

In the second part of measurements, we have used peat briquettes coming from Ukraine. Briquettes were squared logs of size $18 \times 18 \times 20 \mathrm{~cm}(w \times h \times l)$, with an average humidity of $14.6 \%$. Three packages $(12 \mathrm{~kg})$ with four pieces of briquettes were used for measurements. Briquettes were freely put into the storage tank, in which a firewood ember was kept for easier firing.

The recorded values from this series of measurements are shown in Table 2.

Figure 4 shows the effect of boiler performance on emissions of oxygen, carbon dioxide and carbon monoxide in flue gas, and chimney loss at a given performance when burning peat briquettes. With respect to two tests at a $100 \%$ and $30 \%$ boiler performance, we have marked the average value of these tests in the graph. It is obvious from the graph that there was a significant oscillation of measured values, which could have been caused by the fact that this type of fuel is not recommended for use with this boiler type.

Figure 5 shows the effect of boiler performance on levels of nitrogen oxides and nitric oxide in flue gas and flue gas temperature, and the course 
Table 1 Results of emissions for burning peat briquettes

\begin{tabular}{|c|c|c|c|c|c|c|c|c|c|}
\hline \multirow[t]{2}{*}{ No } & \multirow[t]{2}{*}{$\mathrm{O}_{2}$ in $\%$} & \multirow[t]{2}{*}{$\mathrm{CO}_{2}$ in $\%$} & \multicolumn{2}{|c|}{$\mathrm{CO}$} & \multirow[t]{2}{*}{$T_{s}$ in ${ }^{\circ} \mathrm{C}$} & \multirow[t]{2}{*}{$T_{v}$ in ${ }^{\circ} \mathrm{C}$} & \multirow[t]{2}{*}{ qA in $\%$} & \multirow[t]{2}{*}{$\eta$ in \% } & \multirow[t]{2}{*}{$\lambda$} \\
\hline & & & ppm & $\mathbf{m g} \cdot \mathrm{m}^{-3}$ & & & & & \\
\hline 1 & 16.8 & 4.01 & 1,217 & $3,622.0$ & 86.2 & 27.8 & 9.4 & 90.6 & 6.31 \\
\hline 2 & 17.2 & 3.67 & 158 & 519.7 & 61.5 & 26.0 & 6.2 & 93.8 & 5.53 \\
\hline 3 & 17.4 & 3.48 & 922 & $3,201.4$ & 102.6 & 26.9 & 11.4 & 88.6 & 6.22 \\
\hline 4 & 17.6 & 3.74 & 1,172 & $4,308.8$ & 100.9 & 27.1 & 11.7 & 88.3 & 9.02 \\
\hline 5 & 18.5 & 2.42 & 631 & 3,155 & 58.3 & 26.6 & 10.8 & 89.2 & 10.9 \\
\hline 6 & 18.0 & 2.90 & 481 & $2,004.2$ & 48.4 & 26.3 & 9.2 & 90.8 & 7.0 \\
\hline 7 & 19.5 & 1.50 & 785 & $8,340.6$ & 31.7 & 26.3 & 2.1 & 97.9 & 14.0 \\
\hline 8 & 18.1 & 2.81 & 1,472 & $6,344.8$ & 42.7 & 27.0 & 4.2 & 95.8 & 14.0 \\
\hline
\end{tabular}

\begin{tabular}{|c|c|c|c|c|c|}
\hline \multirow[t]{2}{*}{ No } & \multicolumn{2}{|c|}{ NO } & \multicolumn{2}{|c|}{$\mathbf{N O}_{\mathbf{x}}$} & \multirow{2}{*}{$\begin{array}{c}\text { Boiler } \\
\text { performance in \% }\end{array}$} \\
\hline & ppm & $\mathbf{m g} \cdot \mathrm{m}^{-3}$ & ppm & $\mathrm{mg} \cdot \mathrm{m}^{-3}$ & \\
\hline 1 & 26 & 126.9 & 27 & 131.8 & 100 \\
\hline 2 & 91 & 490.9 & 96 & 517.9 & 30 \\
\hline 3 & 31 & 176.5 & 33 & 187.9 & 100 \\
\hline 4 & 56 & 337.6 & 59 & 355.7 & 90 \\
\hline 5 & 21 & 172.2 & 22 & 180.4 & 60 \\
\hline 6 & 60 & 409.9 & 63 & 430.5 & 10 \\
\hline 7 & 16 & 278.8 & 17 & 296.2 & 0 \\
\hline 8 & 29 & 204.9 & 30 & 212.0 & 30 \\
\hline
\end{tabular}

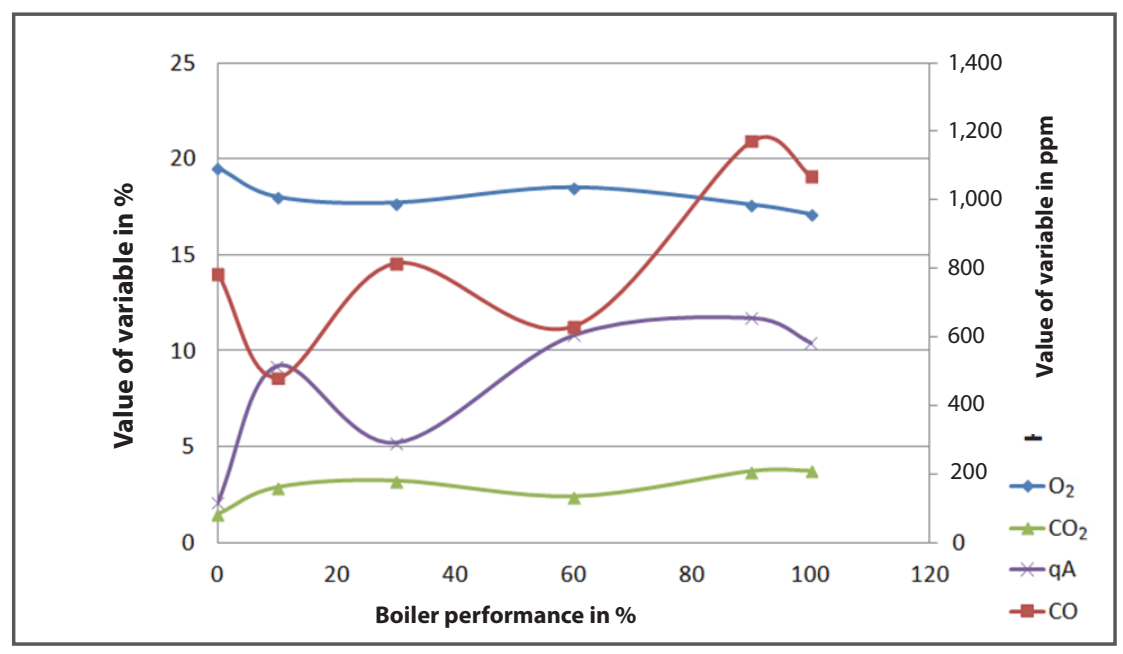

Figure 4 Effect of boiler performance on levels of oxygen, carbon dioxide and carbon monoxide in flue gas, and chimney/vertical loss at given performance

of ambient air temperature during this measurement. The graph indicates the oscillation of emission levels of nitrogen oxides.

Figure 6 illustrates the effect of boiler performance on effectiveness and air surplus. The graph indicates a significant decrease of effectiveness at higher boiler performance, which is most probably caused by the fact that this type of fuel is not recommended for use with this boiler type.

According to Jandačka and Mikulík (2008), the burning of biomass can be considered as neutral in terms of carbon dioxide $\left(\mathrm{CO}_{2}\right)$ emissions. However, it is necessary to take into consideration various technical problems with certain types of biomass such as e.g. straw the characteristic attribute of which is a high chlorine level, where emissions of hydrogen chloride $(\mathrm{HCl})$ cause slag formation and corrosion.

Other authors agree with this opinion and describe biomass as a neutral source of energy (Pepich, 2009; Jandačka, 2007). We also incline to this opinion in the presented contribution; however, the results of tests indicate that emission levels are relatively high, especially for biomass for which the tested heat source was not primarily determined. There were also noticed differences in the temperature of flue gas. The temperature of boiler walls is analysed by Trávníček et al. (2011).

When testing a heat source heating a residential area, Vitázek et al. (2012) came to a conclusion that there are significantly higher emission levels of pollutants by burning biomass as compared to burning natural gas, followed by higher fees for air pollution. However, they also point out to some positives, mostly the overall economic advantage and support of regional employment.

Jandačka and Mikulík (2008) states that waste biomass is a suitable and 


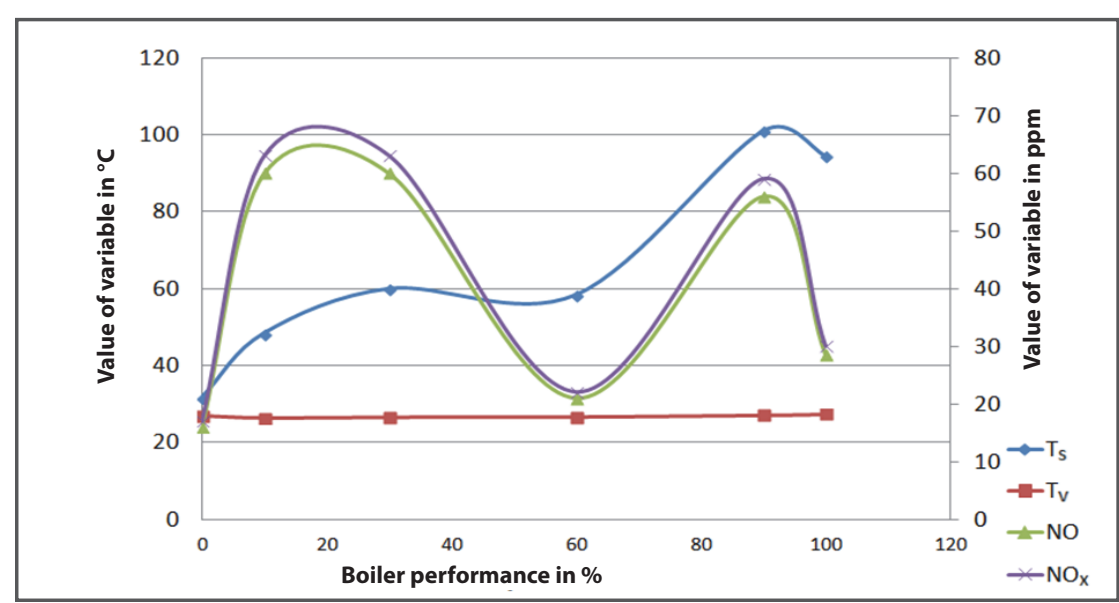

Figure $5 \quad$ Effect of boiler performance on levels of nitrogen oxides and nitric oxide in flue gas and flue temperature, and the course of ambient temperature during measurement

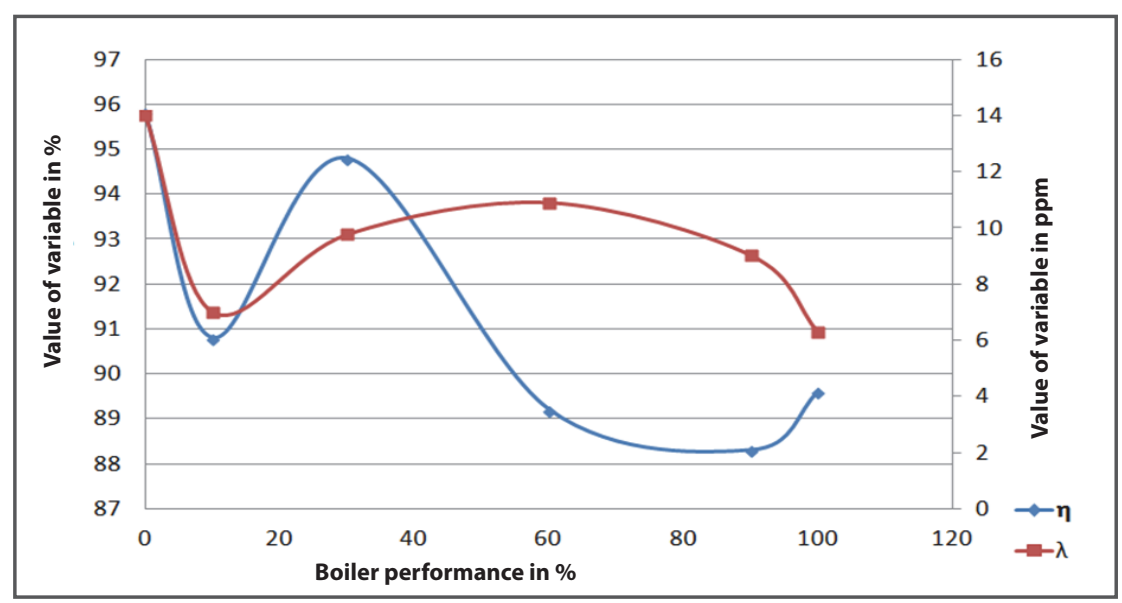

Figure 6 Effect of boiler performance on efficiency and air surplus

especially reasonably priced fuel for households and small heat providers. However, it is necessary to consider the origin or previous purpose of waste because very high emission levels were recorded when burning chipboard waste.

\section{Conclusion}

The results indicate that the most suitable fuel for this boiler type is firewood. During burning, we recorded in average the lowest emission levels and the highest effectiveness, exception for carbon monoxide levels. With other types of burnt biofuels, higher levels of pollutants were recorded in most of measured emissions. In case of peat briquettes and bark briquettes, there were high oscillations, whether depending on the time of measurement or boiler performance.

The results supported the manufacturer's recommendation to
Retrieved from: http://www.vimar.sk/?u1= kotlyvodne\&u2=vigas $025 \& \mathrm{jazyk}=\mathrm{sk}$

DZURENDA, L. 2004. Produkcia oxidov dusíka z procesu spalovania vlhkého dreva niektorých ihličnatých a listnatých drevín. In Acta Mechanica Slovaca, vol. 8, no. 3-A, pp. 87-92.

JANDAČKA, J. - MIKULÍK, M. 2008. Ekologické aspekty spal'ovania biomasy a fosílnych palív [online]. Žilina : Juraj Štefuň - GEORG. 116 pp. ISBN 978-809691617-7. [Retrieved 2012-09-05]. Retrieved from: http://www.biomasa-info.sk/docs/ PriruckaAspekty.pdf

JANDAČKA, J. 2007. Druhy biomasy. In Možnosti lokálneho vykurovania a výroba elektrickej energie z biomasy. [Retrieved 2012-07-15]. Retrieved from: http://www. biomasa-info.sk/docs/05jandacka_s.pdf

PEPICH, ̌̌. 2009. Polnohospodárska biomasa z pohl'adu regionálnej bioenergetiky. In Agrobioenergia - časopis Združenia pre polnohospodársku biomasu, vol. 4, no. 1, pp. 21-24.

PINTER, T. 2013. Posúdenie zdroja tepla pre spal'ovanie biopaliva (diploma thesis). Nitra : SUA. 80 pp.

TRÁVNÍČEK, P. - KUKLA, R. - VÍTĚZ, T. - MAREČEK, J. 2011. Experimental determination of temperatures of the inner wall of a boiler combustion chamber for the purpose of verification of a CFD model. In Acta Universitatis Agriculturae et Silviculturae Mendelianae Brunensis, vol.59, no. 1, pp. 235-242.

VITÁZEK, I. - HAVELKA, J. 2010. Termodynamika spalív z bioplynu. In Acta Techn. Agr., vol. 13, no. 2, pp. 36-40.

VITÁZEK, I. - VITÁZKOVÁ, B. - PLOTH, J. 2012. Produkcia plynných emisií zdroja tepla na biomasu. In Sborník príspěvku 31. mezinárodní konference "Setkání kateder mechaniky tekutin a termomechaniky". Brno : VUT, pp. 245-248. ISBN 978-80-214-4529-1.

\section{Contact address:}

Ivan Vitázek, Slovak University of Agriculture in Nitra, Faculty of Engineering, Department of Transport and Handling, Tr. Andreja Hlinku 2, 949 76 Nitra, Slovak Republic, e-mail: ivan. vitazek@uniag.sk of environmental aspects of machinery interaction on elimination of degradation processes in agrotechnologies of field crops' and project VEGA 1/0857/12 'Reduction of negative impacts of agricultural and transport machines on environment'.

\section{References}

COMPANY MATERIALS. VIMAR - Teplovodný kotol Vigas 25. [Retrieved 2013-2-27]. 